\title{
Potential of Macrophytes for Removing Atrazine from AQueOus SOlution ${ }^{1}$
}

\author{
Potencial de Macrófitas para Remoção de Atrazine de Solução Aquosa
}

\author{
GUIMARÃES, F.P. ${ }^{2}$, AGUIAR, R..$^{2,3}$, KARAM, D. ${ }^{4}$, OLIVEIRA, J.A. ${ }^{3}$, SILVA, J.A.A. ${ }^{4}$, SANTOS, C.L. ${ }^{2}$, \\ SANT'ANNA-SANTOS, B.F. ${ }^{5}$ and LIZIERI-SANTOS, C. ${ }^{2}$
}

\begin{abstract}
The potential of three macrophytes, Azolla caroliniana, Salvinia minima, and Lemna gibba was assessed in this study to select plants for use in environmental remediation contaminated with atrazine. Experiments were carried out in a greenhouse over six days in pots containing Hoagland 0.25 strength nutritive solution at the following atrazine concentrations: 0; 0.01; 0.1; 1.0; $10.0 \mathrm{mg} \mathrm{L}^{-1}$. Decrease in biomass accumulation was observed in the three macrophytes, as well as toxic effects evidenced by the symptomatology developed by the plants which caused their deaths. The chlorosis and necrosis allowed to observe in the plants the high sensitivity of the three species to the herbicide. Plants presented low potential for removal of atrazine in solution when exposed to low concentrations of the herbicide. However, at the $10.0 \mathrm{mg} \mathrm{L}^{-1}$ atrazine concentration, L. gibba and A. caroliniana showed potential to remove the herbicide from the solution $(0.016$ and $0.018 \mathrm{mg}$ atrazine per fresh mass gram, respectively). This fact likely resulted from the processes of atrazine adsorption by the dead material. The percentage of atrazine removed from the solution by the plants decreased when the plants were exposed to high concentrations of the pollutant. Azolla caroliniana, S. minima, and L. gibba were not effective in removing the herbicide from solution. The use of these species to remedy aquatic environments was shown to be limited.
\end{abstract}

Keywords: Azolla caroliniana, Salvinia minima, Lemna gibba, herbicide, bioremediation.

RESUMO - Avaliou-se, neste estudo, o potencial de três macrófitas - Azolla caroliniana, Salvinia minima e Lemna gibba - com vistas à seleção de plantas para remediação de ambientes contaminados por atrazine. Foram realizados experimentos em casa de vegetação durante seis dias, em vasos contendo solução nutritiva Hoagland ( 0,25 de força iônica), nas seguintes concentrações

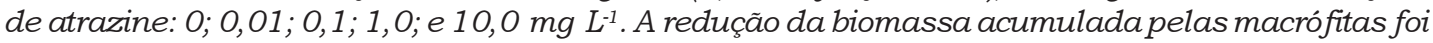
observada, bem como os efeitos de toxidez evidenciados pela sintomatologia desenvolvida nas plantas, os quais causaram sua morte. Clorose e necrose observadas nas plantas mostraram a alta sensibilidade das três espécies ao herbicida. As plantas demonstraram baixo potencial para remoção de atrazine, quando expostas ao herbicida em baixas doses. Entretanto, na concentração de $10,0 \mathrm{mg} \mathrm{L}^{-1}$ de atrazine, L. gibba e A. caroliniana mostraram potencial para remover o herbicida da solução (0,016 e 0,018 mg de atrazine por grama de massa fresca, respectivamente). Esse fato provavelmente resultou do processo de adsorção de atrazine pela matéria morta. A porcentagem de atrazine removida da solução pelas plantas diminuiu quando estas foram expostas a altas concentrações do poluente. Azolla caroliniana, S. minima e $\boldsymbol{L}$. gibba não foram eficazes na remoção do herbicida na solução. A utilização dessas espécies para sanar ambientes aquáticos mostrou-se limitada.

Palavras-chave: Azolla caroliniana, Salvinia minima, Lemna gibba, herbicida, biorremediação.

Recebido para publicação em 10.7.2011 e aprovado em 10.11.2011.

2 Departamento de Biologia Vegetal, Universidade Federal de Viçosa - DBV/UFV, Av P.H. Rolfs s/n, 36570-000 Viçosa-MG; ${ }^{3}$ Corresponding author, <roaguiar@ufv.br>; ${ }^{4}$ Empresa Brasileira de Pesquisa Agropecuária - Embrapa Milho e Sorgo, Rod. MG 424 Km 45, 35701-970 Sete Lagoas-MG; ${ }^{5}$ Instituto de Ciências Agrárias, Universidade Federal de Minas Gerais - UFMG, Av. Universitária, 1000, Caixa Postal 135, Montes Claros-MG. 


\section{INTRODUCTION}

The world pesticide market currently moves about US $\$ 13$ billion per year, and herbicides account for most of these products (Ueta et al., 1999, 2004; Sindag, 2003; Cerdeira et al., 2005; IBGE, 2005). Only in 2009, Brazil's market sold 725,000 tons of herbicides formulations (Menten et al., 2010). Of these, atrazine (2-chloro-4-ethylamino-6-isopropylamino-striazin) deserves special attention because it is one of the most commonly applied pesticides in the world (Hayes et al., 2010), according to the United States Department of Agriculture (Anderson \& Noyes, 2002; EPA, 2003a).

Atrazine is a triazinic herbicide used in corn, sugarcane, and sorghum crops and may also be used in non agricultural areas such as golf courses, residential lawns, and recreational areas (Ueta et al., 1999; EPA, 2003a; Rodrigues \& Almeida, 2005). Atrazine is a pre and post-emergence herbicide, photosyntesis disrupter, which have an impact on the electron acceptors around PSI and PSII. It blocks the electron transport in photosynthesis, leading to a reduction in photosynthetic oxygen production (Mohammad et al., 2010), affecting the carbon assimilation in the target plant.

Data on the use of atrazine causes concern because it shows high persistence in soils and slow degradation, and is, therefore, considered a potential contaminant of soils, surface, and underground water (Health Canada, 1993; Ueta et al., 1999, 2004; Andersona et al., 2002; EPA, 2003a), in addition to causing hormonal problems in human beings and being a potential carcinogenic agent (EPA, 2003a). In several countries, water courses adjacent to agricultural areas contain quantities of pesticides whose maximum concentration limits in water are regulated in specific lows. In the USA, the maximum acceptable atrazine concentration in water for consumption use is $0.003 \mathrm{mg} \mathrm{L}^{-1}$ (EPA, 2005), while in Brazil the maximum permitted is $0.002 \mathrm{mg} \mathrm{L}^{1}$ (Brasil, 2005).

Some plants such as corn, sorghum, and sugarcane, are tolerant to atrazine and can detoxify the herbicide before it inhibits photosynthesis. The different tolerance levels of these species relies on the activity of glutathione-S-transferase, an enzyme that links one atrazine molecule to one glutathione molecule, being translocated to the vacuole, therefore preventing the herbicide action (De Prado et al., 1995; Prade et al., 1998; Rodrigues \& Almeida, 2005; Marcacci et al., 2006). Thus, atrazine can be used as an herbicide on these crops because it only affects weed photosynthesis, without altering crop yield (EPA, 2003b).

There are plants tolerant to atrazine, indicating that tolerance mechanisms do exist and can be used in phytoremediation programs. Many plants can absorb organic compounds, metabolizing them or even releasing exudates that stimulate the microbial population and consequently degrade or complex the pollutants while still in the rhizosphere (Burken \& Schnoor, 1996). It is generally more difficult to work with organic contaminants because of their molecular diversity, the complexity of analysis, and the constant transformations that they are subject to (Cunningham \& Ow, 1996), in addition to the possibility of transforming the pollutants in sub products that are more toxic than the original substance. Some microorganisms (bacteria, micro-algae, and fungi) have also shown a capacity to partially or totally biodegrade the atrazine molecule, resulting in the formation of ammonia $\left(\mathrm{NH}_{3}\right)$ and carbon dioxide $\left(\mathrm{CO}_{2}\right)$ (Ueta et al., 1999, 2004; Gao et al., 2000; Andersona et al., 2002; Lanyi \& Dinya, 2003, 2005).

The market demand to implement decontamination systems for polluted water is growing up rapidly, also calling for the search for low-cost technologies. In this context, phytoremediation is an effective alternative to decontaminate polluted environments. It is extremely important to identify and select tolerant plant species that can remove and/ or metabolize atrazine because this will allow its application to decontaminate impacted environments. Aquatic phytoremediation with floating aquatic plants for nutrient removal has a large potential, especially in tropical and subtropical regions of the world (Olguin et al., 2008). Among these species may be cited: Azolla caroliniana Willd, Salvinia minima Baker and Lemna gibba Linnaeus (Mkandawire \& Dudel, 2005; Olguín et al., 2008; Hayes, 2010; Obek \& Sasmaz, 2011). 
Azolla caroliniana is a small, floating aquatic fern, widely distributed in the tropics and in the Americas, and usually found in stagnant waters (Tryon \& Tryon, 1982). It possesses thin roots and overlapping bilobed leaves, and it grows quickly, thus justifying its use in plant remediation research. Salvinia minima is a floating aquatic pteridophyte, found in lakes and rivers in various parts of the world (Tryon \& Tryon, 1982). Lemna gibba is a small, floating aquatic monocotyledon, that grows fast and adapts easily to various environmental conditions, whose phenology characteristics can facilitate the phytoremediation. It is widely distributed in the world, where it plays an important role in extracting and accumulating metallic ion from the waters (Zayed et al., 1998).

The objective of this study was to examine the potential of the macrophyte species A. caroliniana, S. minima, and L. gibba in the removal of atrazine from solutions for use in phytoremediation programs.

\section{MATERIALS AND METHODS}

\section{Plant material}

The floating aquatic macrophytes A. caroliniana, S. minima, and L. gibba were collected from tanks at the Botanical Garden of the Plant Biology Department at the Universidade Federal de Viçosa, Viçosa, Minas Gerais State, Brazil, in January 2005.

After disinfection with $1 \%$ sodium hypochlorite solution, the plants were cultivated in the greenhouse on plastic trays containing Hoagland 0.25 strength solution (Hoagland \& Arnon, 1950). Plants in the experiments were derived from two mother plants, which resulted in minimal genotypic and pre-experimental variations (Outridge et al., 1991).

\section{Plants exposure to atrazine}

The experiments were assessed with $1.5 \mathrm{~g}$ of plant fresh mass per sample unit, which were transferred to black pots containing $1.5 \mathrm{~L}$ Hoagland solution at the following atrazine concentrations: $0 ; 0.01 ; 0.1 ; 1.0 ; 10.0 \mathrm{mg} \mathrm{L}^{-1}$. The pots, with five replications per treatment, were maintained in the greenhouse for six days.
Plants were weighed every two days to obtain the fresh mass, and then returned to their respective pots. At the end of the experiment, $0.5 \mathrm{~g}$ of fresh mass were placed in a freezer for later atrazine extraction. The rest of the fresh mass was taken to an oven at $70{ }^{\circ} \mathrm{C}$, for 3 days, for dry mass determination. Total dry mass was estimated considering the $0.5 \mathrm{~g}$ fresh mass used for atrazine extraction. The initial dry mass was calculated from the mean obtained in five replications, each containing $1.5 \mathrm{~g}$ of fresh mass per species (Cedergreen et al., 2004).

Commercial atrazine Gesaprin ${ }^{\circledR} 500$ (Giba-Geigy), whose active ingredient corresponds to $500 \mathrm{~g} \mathrm{~L}^{-1}$, was used in the experiments.

Minimum temperature in the greenhouse was $17^{\circ} \mathrm{C}$, and the maximum one $38^{\circ} \mathrm{C}$. The volume of water was completed daily with deionized water to compensate for water loss through transpiration and evaporation (Aksorn $\&$ Visoottiviseth, 2004). Plastic pots used in the experiments were lined with polyethylene bags to prevent their contamination and facilitate storage of the residues for later disposal in a specialized waste facility. Experiments were carried out in a greenhouse at the Federal University of Viçosa. A complete randomized design was used.

\section{Atrazine measurements}

Extraction was performed with $0.5 \mathrm{~g}$ of fresh mass from each sample unit to quantify atrazine in whole fresh plants. Samples were squashed in $10 \mathrm{~mL}$ methanol solution (methanol: water, $1: 1 . \mathrm{v}: \mathrm{v}$ ), followed by homogenization and centrifugation at $1.500 \mathrm{~g}$ for 10 minutes (Lawrence et al., 1996; Garcinuno et al., 2003). Supernatant was analyzed by High Performance Liquid Chromotography (HPLC, Class-LC 10, Shimadzu, Japan, 1992), of the Brazilian Agricultural Research Corporation - Embrapa Maize and Sorghum Research Center in Sete Lagoas, Minas Gerais State. A Supelcosil LC $18 \mathrm{~S}(150 \times 4.6 \mathrm{~mm}, 5 \mu \mathrm{m})$ type-column was used to determine the atrazine and the mobile phase was a $\mathrm{MeOH}: \mathrm{H}_{2} \mathrm{O}(60: 40)$ solution, $20 \mu \mathrm{L}$ injected volume, and $1 \mathrm{~mL}$ per minute elution flow. 


\section{Efficiency of atrazine removal}

The removal efficiency of atrazine from solution was estimated as the percentage of atrazine removed by the plant. The amount of atrazine in solution was considered as $100 \%$. Atrazine concentration absorbed by the plants $\left(\mathrm{mg} \mathrm{gFM}{ }^{-1}\right)$ was multiplied by the fresh mass produced during the exposure period to the herbicide, producing, therefore, the total amount of atrazine removed from solution.

\section{Symptomatology}

A photographic record was made of the plants exposed to different atrazine concentrations using a digital camera (Sony DSC-S60). A stereoscopic microscope was also used (Olympus, Micronal VM VMT, Brazil) to show the symptoms of the aquatic macrophytes grown in solution containing atrazine.

Shoots of $A$. caroliniana and $L$. gibba control and the plants exposed to the $0.1 \mathrm{mg} \mathrm{L}^{-1}$ atrazine concentration were examined under scanning electron microscope (model Leo 1430 VP, Zeiss, Cambridge, England) of Universidade Federal de Viçosa Microscopy Center. Plants were fixed in glutaraldehyde, post-fixed in osmium tetroxide, and, following successive washings, dehydrated in ethylic series. Samples were dried in a critical point apparatus (model CPD-030, Bal-Tec, Balzers, Liechtenstein). After drying, samples were covered in gold using the catodic spraying process in Sputter Coater equipment (model FDU 010, Bal-Tec, Balzers, Liechtenstein).

\section{Statistical analysis}

Analysis of variance (Anova) was used at the level of $5 \%$ probability to verify the effects of different atrazine concentrations on the absorption and on biomass accumulation by the macrophyte species. Tukey test was used to compare the means of treatments.

\section{RESULTS AND DISCUSSION}

\section{Biomass accumulation}

The amount of dry mass produced per day by the three macrophyte species was affected by the atrazine concentration in solution, according to statistical analysis (Figure 1). The higher and lower atrazine concentration in solution and the biomass accumulated by the three species (A. caroliniana, S. minima, and L. gibba) are shown in Figure 1.

Azolla caroliniana, when exposed to atrazine solutions of 0.01 and $0.1 \mathrm{mg} \mathrm{L}^{-1}$, gained 0.011 and $0.007 \mathrm{~g}$ dry mass per day, respectively. These values were statistically similar to the $0.006 \mathrm{~g}$ produced by plants in the control group ( $0 \mathrm{mg} \mathrm{L}^{-1}$ of atrazine). Plants exposed to the higher atrazine concentrations (0.01 and $0.1 \mathrm{mg} \mathrm{L}^{-1}$ ) did not exhibit any biomass accumulation (Figure 1). Salvinia minima gained $0.020 \mathrm{~g}$ dry mass per day when exposed to $0.01 \mathrm{mg} \mathrm{L}^{-1}$ atrazine, similar to $0.024 \mathrm{~g}$ showed by control group. No biomass accumulation was observed in plants exposed to the $0.1,1.0$, and $10.0 \mathrm{mg} \mathrm{L}^{-1}$ concentrations (Figure 1). Lemna gibba followed the same pattern shown by $S$. minima, presenting $0.015 \mathrm{~g}$ dry mass growth per day when exposed to $0.1 \mathrm{mg} \mathrm{L}^{-1}$, that was shown to be similar to $0.017 \mathrm{~g} \mathrm{day}^{-1}$ exhibited by the control group. Furthermore, no growth was observed in plants exposed to the other two atrazine concentrations (Figure 1).

Atrazine solution reduced cultures in about $66 \%$ of Synechococcus elongatus cyanobacterium dry biomass and arrested growth of the green microalga Chlorella vulgaris, under concentration $0.75 \mu \mathrm{M} \mathrm{L}^{-1}$, in

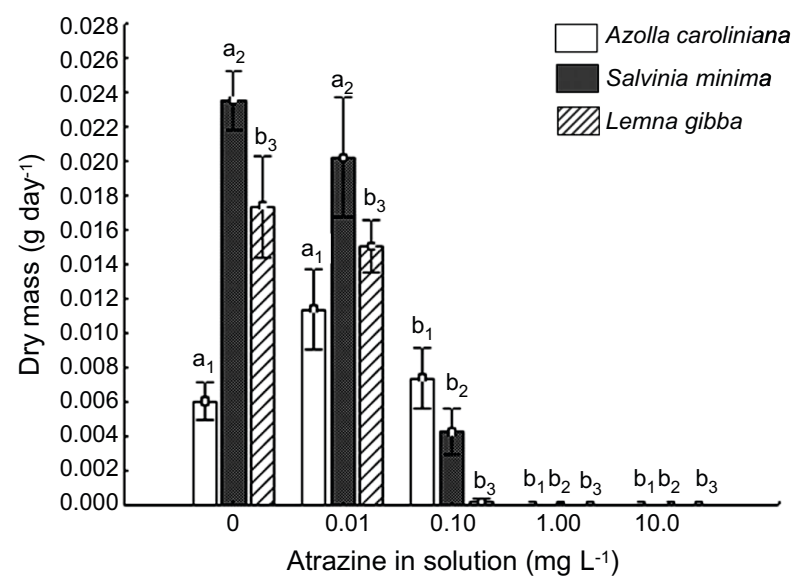

Figure 1 - Biomass accumulation by plants under different atrazine concentrations. Bars represent standard errors. Different letters indicates represent different means by Tukey test. 
a screening study of efficient organisms to the removal of triazine herbicides from freshwater systems (Gonzáles-Barreiro et al., 2006). Growth of Elodea canadensis and Myriophyllum spicatum was not affected under atrazine levels, indicating that herbicide exposure did not impair plant development (Knauert et al., 2010).

All the abaxial leaf surface of the aquatic macrophytes investigated was in contact with water. This fact allowed atrazine to be absorbed by two different mechanisms: absorption by the roots and translocation of the herbicide to the leaves, and direct absorption by leaves (Rodrigues \& Almeida, 2005).

\section{Atrazine absorption by aquatic macrophytes}

The higher atrazine concentration in solution and the greater herbicide absorption by the three macrophytes are shown in Figure 2 .

Azolla caroliniana accumulated on average $0.003,0.004$, and $0.018 \mathrm{mg} \mathrm{gFM}^{-1}$ at concentrations of $0.1,1.0$, and $10.0 \mathrm{mg} \mathrm{L}^{-1}$, respectively. Salvinia minima accumulated $0.002,0.004$, and $0.013 \mathrm{mg} \mathrm{gFM}^{-1}$ while L. gibba accumulated 0.002, 0.003, and $0.016 \mathrm{mg}$ atrazine per gram of fresh mass, when exposed to atrazine concentrations of $0.1,1.0$, and $10.0 \mathrm{mg} \mathrm{L}^{-1}$, respectively.

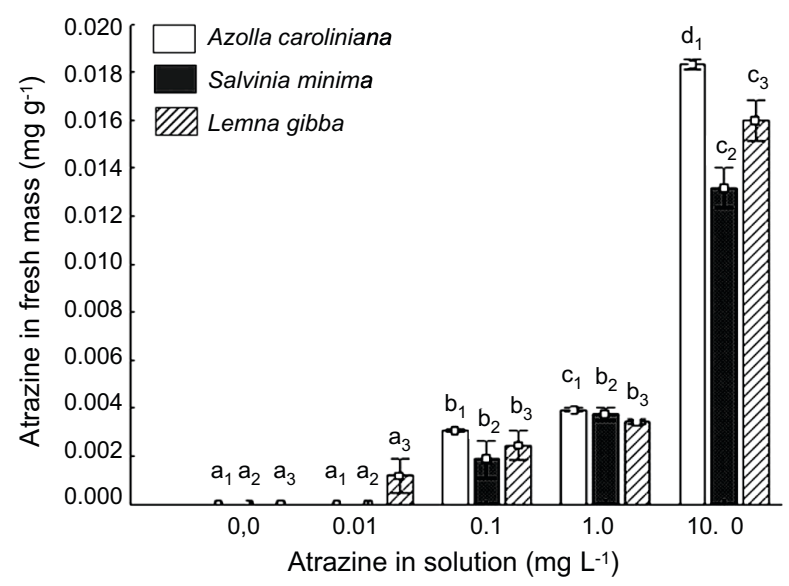

Figure 2 - Atrazine concentrations in the macrophytes under different treatments. Bars represent standard errors. Different letters indicate different means by the Tukey test
Lemna gibba absorbed $0.001 \mathrm{mg}$ atrazine when exposed to $0.01 \mathrm{mg} \mathrm{L}^{-1}$ herbicide solution, unlike the other species, it did not register herbicide absorption at this concentration. However, the amount of herbicide absorbed by the Lemna gibba at this concentration $\left(0,01 \mathrm{mg} \mathrm{L}^{-1}\right)$ was negligible. The toxicity of atrazine to Lemna gibba was detected at $89 \mathrm{ppb}$ (EC50), under 7 days exposure. The growth was inhibited after 7 days exposure, however atrazine was not lethal to L. gibba at $3200 \mathrm{ppb}$ for 28 days exposure. (Mohammad et al., 2010).

The three macrophytes species studied showed the same potential for atrazine removal from the water, differing only at the $10.0 \mathrm{mg} \mathrm{L}^{-1}$ atrazine concentration (Figure 2). At this concentration, A. caroliniana and L. gibba removed 0.018 and $0.016 \mathrm{mg} \mathrm{gFM}^{-1}$ respectively, which were higher than the $0.013 \mathrm{mg}$ of atrazine removed by $S$. minima (Anova, $\mathrm{df}=2, \mathrm{~F}=13.53, \mathrm{p}=0.000843$, and the Tukey Test).

Good results have been reported of plants with phytoremedial potential thriving in soils contaminated with herbicides. Also, other pollutants of water have been removed by these species. Studies by Burker \& Schnoor (1996, 1997) showed that Populus deltoides nigra DN34 absorbed about $90 \%$ of atrazine from the environment in 10 days, without showing characteristic symptoms of toxicity, such as chlorosis. Singh et al. (2004) showed that Pennisetum clandestinum can degrade $45 \%$ of atrazine present in the soil in 80 days, without presenting characteristic symptoms of atrazine toxicity.

These data were satisfactory because the half life of atrazine in the field is 60 days (Rodrigues \& Almeida, 2005). Resistant plants exhibited herbicide detoxification mechanisms that involved the action of glutathione, via glutathione-S- transferase enzyme activity (De Prado et al., 1995; Prade et al., 1998; Marcacci et al., 2006). Warwick (1991) suggested that the atrazine resistance mechanism of several plants was also related to the genetic modifications of genes codifying proteins from the photosystem II.

Atrazine degradation in the environment is also strongly related to the presence of 
microorganisms (Burken \& Schnoor, 1996; Anderson et al., 2002; Pires et al., 2003a, b; Singh et al., 2004). The use of macrophytes with great root systems is recommended to create an environment suitable for microbial activity. However, this study was concerned in verifying the potential of the plants for use in remediation studies only, and plants were disinfected previously to prevent microorganism interference and proliferation in the experiments.

It is important to point out that the remediation efficiency of atrazine in solution decreased with the increase in the concentration of the pollutant in the environment, thus showing the efficiency of using the phytoremediation technique for environments with low to medium contamination (Cunningham \& Ow, 1996; Garbisu \& Alkorta, 2001; Williams, 2002; Tsao, 2003; Suresh \& Ravishankar, 2004; PilonSmits, 2005).

\section{Efficiency of atrazine removal}

The percentage of atrazine absorbed by the plants decreased with the increase in the herbicide concentration in solution. Azolla caroliniana, L. gibba, and S. minima removed a greater percentage of atrazine when exposed to the $0.1 \mathrm{mg} \mathrm{L}^{-1}$ (Figure 3). Azolla caroliniana removed 6.56; 0.43 , and $0.16 \%$, L. gibba removed $5.07 ; 0.38$, and $0.15 \%$ while $S$. minima

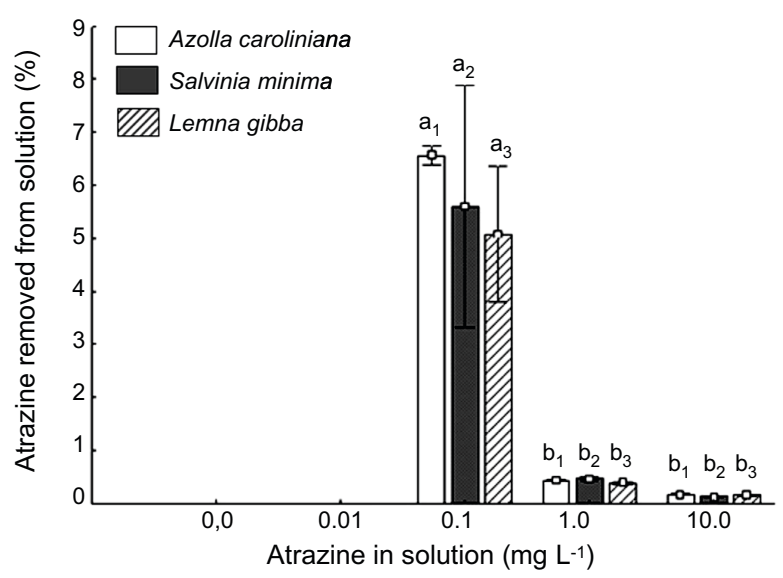

Figure 3 - Atrazine removal efficiency (\%) from the solution by the plants under different treatments. Bars represent standard errors. Different letters indicates different means by the Tukey test. removed $5.6 ; 0.45 ; 0.12 \%$ of atrazine, in the respective treatments $0.1,1.0,10.0 \mathrm{mgL}^{-1}$.

The three species, however, showed the same pattern of efficiency when exposed to the same atrazine concentrations (Figure 3). Lemna gibba removed small quantities of atrazine when exposed to the solution of $1.0 \mathrm{mg} \mathrm{L}^{-1}$ herbicide concentration, maintaining unaltered the dry and fresh mass gain and showing low potential for atrazine removal at this concentration. The three macrophytes studied removed the same percentage amount of atrazine from the solution at $0.1 \mathrm{mg} \mathrm{L}^{-1}$. However, A. caroliniana and $L$. gibba produced less fresh mass than S. minima at the same concentrations. As they showed the same herbicide removal efficiency, it might be recommended that these plants were used as bioremedies because they showed less biomass gain and they decreased the volume of plant residue to be treated later. Differently to this study, the Azolla species (Azolla pinnata) presented higher potential to accumulate $\mathrm{Hg}$ pollutant, compared with other macrophyte species: Vallisneria spiralis (Rai \& Triphati, 2009). Marcacci et al. (2006) observed the potential of Chrysopogon zizanioides in remedying atrazine effects when the plants were cultivated in water culture solution. This species is phylogenetically close to sorghum, which is an atrazine resistant crop. Chrysopogon zizanioides showed detoxification processes involving glutathione action, in leaves, similar to sorghum plants and was, therefore, extremely positive for use for decontaminating the environment. Lemna gibba, because of it is a monocotyledon, may also possesses similar detoxifying mechanisms involving glutathione. Furthermore, some Lemnaceae species are considered tolerant to triazinic herbicides (Fairchild et al., 1998). Similar tolerance mechanisms are common amongst evolutionary close species. Therefore, phylogenetically close species may possess the same resistance mechanisms. However, at high atrazine concentrations in the medium, at the end of six days, L. gibba presented chlorosis and the plants died, showing a possible inefficiency of their detoxification mechanisms.

Although abundant biomass production was a desirable characteristic for remediation 
purposes (Cunningham \& Ow, 1996; Schnoor, 1997; Williams, 2002; Pilon-Smits \& Pilon, 2002; Pilon-Smits, 2005), if the removal efficiency were the same for the three species, the use of the plant that produced less biomass could be recommended. Thus, the use of A. caroliniana and $L$. gibba would be indicated to remedy environments with concentrations of $0.1 \mathrm{mg} \mathrm{L}^{-1}$ atrazine in the water, because they produced less fresh mass. However, A. caroliniana produced less dry mass and, therefore, its use would be more advantageous than that of $L$. gibba.

When exposed to $0.1 \mathrm{mg} \mathrm{L}^{-1}$ of atrazine, the three aquatic species removed the same percentage of the herbicide from solution $(0.42 \%)$, but the plants were dead, what did not favor the potential of any species for remediation.

At $10 \mathrm{mg} \mathrm{L}^{-1}$ of atrazine, A. caroliniana and L. gibba presented greater efficiency for removal of the herbicide in solution than S. minima. It is suggested that this fact is associated to the herbicide absorption processes in plant tissues. As no media was used to remove the atrazine absorbed in the macrophytes leaves and the species were dead at the end of the experiment, the high atrazine concentration may be associated to the greater contact surface that the leaves had with the solution because of the small size of the plants. Therefore, it is important to verify the capacity of these macrophytes to absorb atrazine with experiments carried out with dead plants. If the potential adsorption is greater than that of absorption, the use of dead organic material to remove atrazine from polluted aquatic environments would be advantageous, because there would be no need to monitor plant growth in the environment, thus avoiding disorganized proliferation of the species in the environment.

\section{Symptomatology}

The plants began to exhibit symptoms of toxicity caused by atrazine on the second day of exposure to the herbicide at the concentrations of 1.0 and $10 \mathrm{mg} \mathrm{L}^{-1}$. The leaf morphology of $A$. caroliniana, S. minima, and L. gibba are shown in Figures 4A, C, and E. Azolla caroliniana (Figure 4B) and S. minima
(Figure 4D) presented necrosis on all leaves while L. gibba (Figure 4F) showed leaf chlorosis. At the end of six days, the three species were dead. Prolonged exposure of Lemna minor to higher concentrations of both Arsenic (III) and Arsenic (V) resulted in a decrease in activity for superoxid dismutase, a antioxidant enzyme, which protects the plants (Duman et al., 2010).

The atrazine action mode consists of blocking the photosystem II electron flow, preventing energy and reduction power production, essential for the carbon assimilation stage in photosynthesis (Brian, 1969; Health Canada, 1993; De Prado et al., 1995; EPA, 2003b). Atrazine causes phytotoxicity, promoting chlorosis and necrosis manifestations, and leading susceptible plants to death. Photosynthesis blockage can be diagnosed by chlorosis and necrosis in the leaves, lack of biomass accumulation, followed by plant death. These symptoms were observed
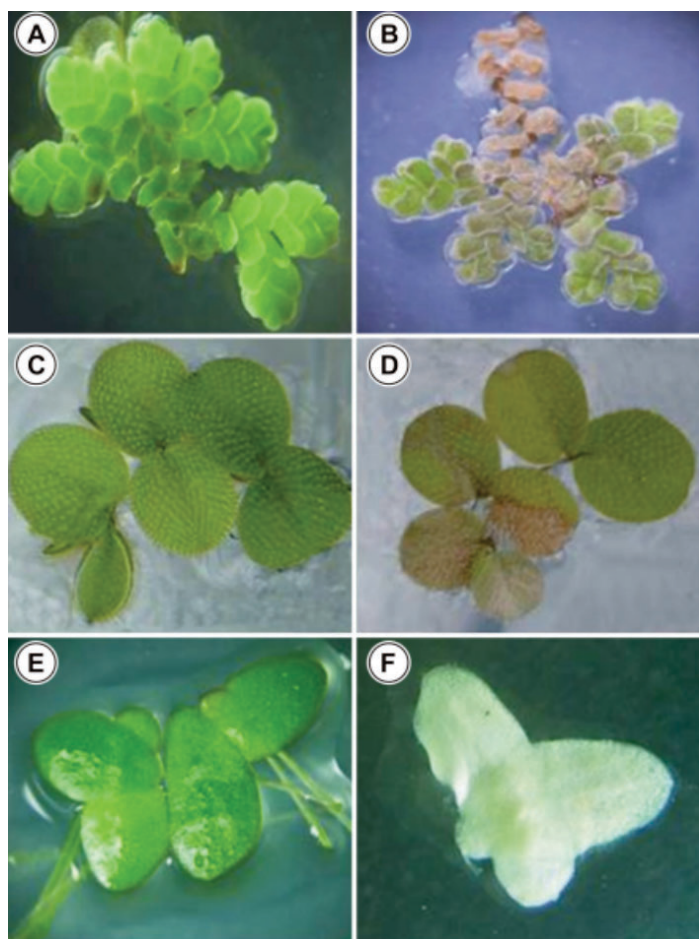

Figure 4 - Symptomatology of plants exposed to $1.0 \mathrm{mg} \mathrm{L}^{-1}$ atrazine. (A and B). A. caroliniana. A. Healthy leaves. B. Leaves necrosis process. (C and D). S. minima. C. Healthy leaves. D. Leaf necrosis process. (E and F). Lemna gibba. E. Healthy leaves. F. Leaf chlorosis process. 
in the three macrophytes species when they were exposed to concentrations higher than $1.0 \mathrm{mg} \mathrm{L}^{-1}$ of the herbicide. On these grounds, it is likely that A. caroliniana, S. minima, and L. gibba do not possess mechanisms to tolerate and atenuate the effects of atrazine at the concentrations studied, showing the low efficiency in remedying environments contaminated by the herbicide.

\section{Scanning electron microscopy}

In the control treatment, the young leaf of $A$. caroliniana appeared intact with welldefined cell shape and turgidity (Figures 5A and 5B). The leaf blade of plants_exposed to $1.0 \mathrm{mg} \mathrm{L}^{-1}$ atrazine for three days showed epidermis cells with plasmolised aspect resulting in the curling of leaf edges (Figures 5C and 5D). Colony of cyanobacteria from the Anabaena genus was detected in the A. caroliniana leaves.

The leaf micromorphology of L. gibba is shown in Figures 6A and 6B. Epidermis cells with disorganized and plasmolised aspect

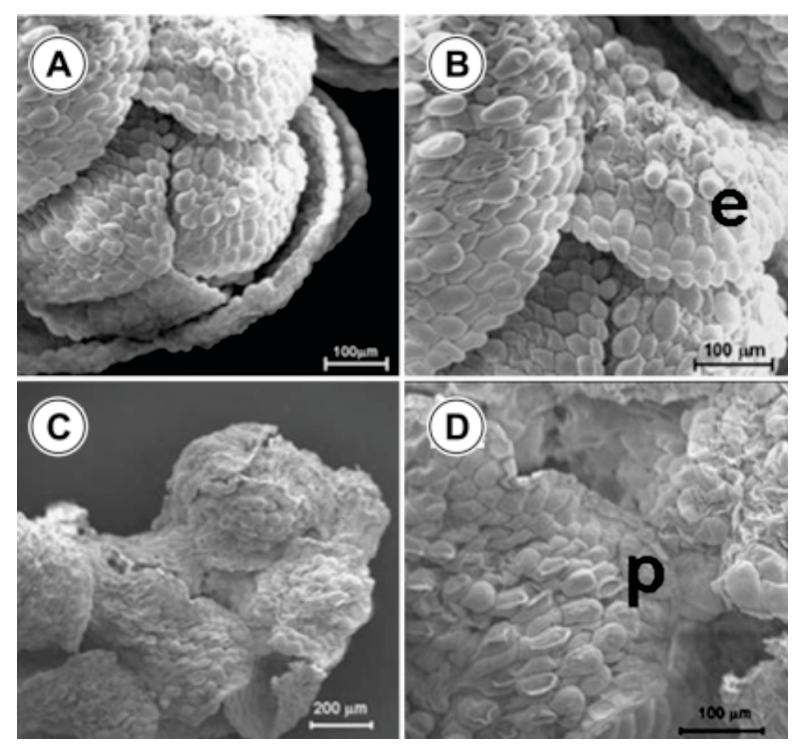

Figure 5 - Leaf surface of $A$. caroliniana (scanning electron micrographs). (A and B). Plants cultivated in Hoagland solution for six days. (C and D). Plants cultivated in Hoagland solution containing $1.0 \mathrm{mg} \mathrm{L}^{-1}$ of atrazine for three days. A. Detail of the young and healthy leaf edges. B. Details of normal and turgid epidermis cells of healthy leaves (e). C. General view of damaged leaf. D. Damaged leaf: curled leaf edges and epidermis cells with plasmolised aspect (p). associated with epicuticular wax erosion occurred when plants were exposed to $1.0 \mathrm{mg} \mathrm{L}^{-1}$ of atrazine for three days (Figure 6C). Stomata, present only in the adaxial surface, remained closed and the guard cells were damaged (Figure 6C). The root apical meristem presented cells with plasmolised aspect (Figure 6D).

Rice et al. (1997) showed that the presence of aquatic vegetation and tolerance to herbicides can accelerate the removal and biotransformation of atrazine in water. Ceratophyllum demersun, Elodea Canadensis, and Lemna minor removed 58.3, 36.8, and 15\% of atrazine from water, respectively, while the macrophytes investigated in the present study, A. caroliniana, S. minima, and L. gibba, removed, respectively, 6.5, 5.1, and $5.6 \%$ of atrazine from solution. Furthermore, chlorosis followed by plant death might be an indication that the plants have inefficient atrazine detoxification mechanisms (Burken \& Schnoor, 1996; Burken \& Schnoor, 1997) and

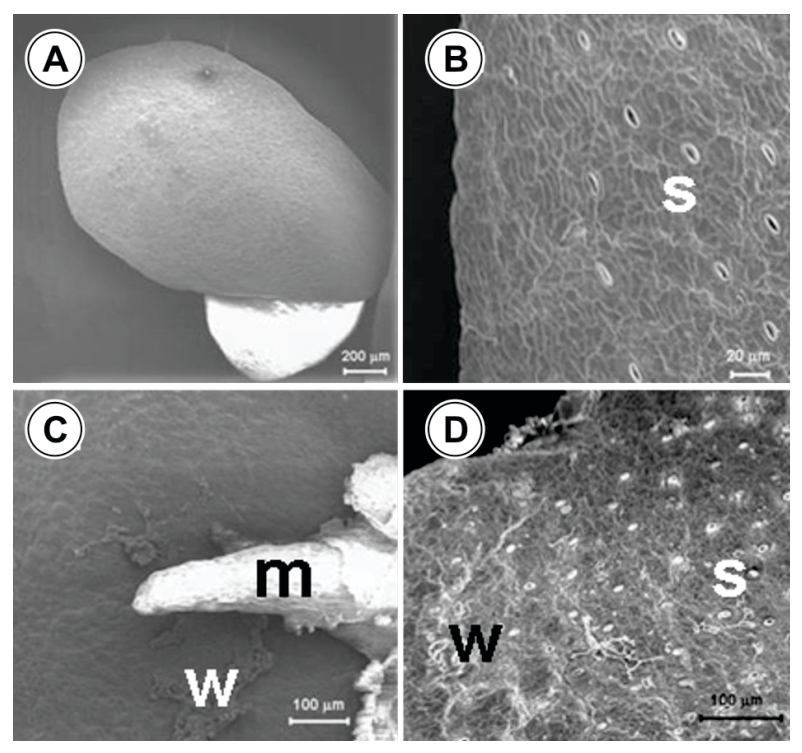

Figure 6 - Leaf surface of L. gibba (scanning electron micrographs). (A and B). Plants cultivated in Hoagland solution for six days. (C_and D). Plants cultivated in Hoagland solution containing $1.0 \mathrm{mg} \mathrm{L}^{-1}$ of atrazine for three days. A. General view of the adaxial leaf surface. B. Detail of the epidermis with turgid cells and normal stomata (s). C. Abaxial surface with epicuticular wax erosion (w) and cells with plasmolised aspect: root apical meristem damaged (m). D. Adaxial surface with disorganized and plasmolised cells and epicuticular wax erosion (w): stomata (s) were closed and the guard cells were damaged. 
showed a low efficiency for remedying aquatic environments contaminated by the herbicide.

Atrazine, a photosynthetic inhibitor, caused decrease in biomass accumulation of the aquatic floating macrophytes and toxic effects, leading to plant death. The chlorosis and necrosis on leaves showed the low sensitivity of these species to the herbicide.

Of the three species studied, A. caroliniana and $L$. gibba presented the same greater potential for atrazine removal from the solution when exposed to high concentrations.

The three species studied were not potentially effective in remedying atrazine dissolved in water.

\section{ACKNOWLEDGMENTS}

The authors thank Federal University of Viçosa and Brazilian Agricultural Research Corporation - Embrapa Maize and Sorghum Research Center, for infrastructure and financial support. F. Guimarães thanks the Brazilian Agricultural Research Corporation for a two-year fellowship, and thanks F.C.C. Barreto and J. E. Peçanha, students of Federal University of Viçosa, for many helpful discussions in the course of this work.

\section{LITERATURE CITED}

AKSORN, E.; VISOOTTIVISETH, P. Selection of suitable emergent plants for removal of arsenic from arsenic contamined water. Sci. Ásia, v. 30, n. 2 p. 105-113, 2004.

ANDERSON, C.; NOYES, S. L. U. Agricultural chemical usage. 2002. Disponível em: <http://www.nass.usda.gov> Acesso em: 12 de nov. de 2006.

ANDERSONA, K. L.; WHEELERB, K. A.; ROBINSONB, J. B. Atrazine mineralization potential in two wetlands. Water Res., v. 36, n. 19, p. 4785-4794, 2002.

BRIAN, R. C. The classification of herbicides and types of toxicity. In: AUDUS, L. J., (Ed.). The physiology and biochemistry of herbicides. London: Academic Press, 1969. p. 1-37.

BURKEN, J. G.; SCHNOOR, J. L. Phytoremediation: Plant uptake of atrazine and role of root exudates. J. Environ.

Eng., v. 122, n. 11, p. 958-963, 1996.

BURKEN, J. G.; SCHNOOR, J. L. Uptake and metabolism of atrazine by poplar trees. Environ. Sci.Technol., v. 31, n. 5, p. 1399-1406, 1997.
CEDERGREEN, N.; STREIBIG, J. C.; SPLIID, N. H. Sensitivity of aquatic plants to the herbicide metsulfuronmethyl. Ecotoxicol. Environ. Saf., v. 57, n. 2, p. 153-161, 2004.

CERDEIRA, A. L. et al. Herbicide leaching on a recharge area of the Guarany Aquifer in Brazil. J. Environ. Sci.

Health., v. 40, n. 1, p. 159-165, 2005

BRASIL. Conselho Nacional de Meio Ambiente. Resolução no 357, de 17 de março de 2005; 2006. Disponível em: $<$ http://www.mma.gov.br.>. Acesso em: 28 jun. 2006.

CUNNINGHAM, S.; OW, D. W. Promises and prospects of phytoremediation. Plant Physiol., v. 110, n. 3, p. 715-719, 1996.

DE PRADO, R.; ROMERA, E.; MENENDEZ, J. Atrazine detoxification in Panicum dichotomiflorum and target site Polygonum lapathifolium. Pestic. Biochem. Physiol., v. 52, n. 1, p. 1-11, 1995.

DUMAN, F.; OZTURK, F.; AYDIN, Z. Biological responses of duckweed (Lemna minor L.) exposed to the inorganic arsenic species As (III) and As (V): effects of concentration and duration of exposure. Ecotoxicology, v. 19, n. 5, p. 983-993, 2010.

EPA. Atrazine interim registration eligibility decision (IRED) Q\&A's; 2003a. Disponível em: <http:// www.epa.gov>. Acesso em: 27 maio 2004.

EPA. Atrazine: analysis of risks. 2003b. Disponível em: $<$ http://www.epa.gov>. Acesso em: 27 maio 2004.

EPA. List of Drinking Water Contaminants \& MCLs 2005. Disponível em: <http://www.epa.gov>. Acesso em: 20 jun. 2006

FAIRCHILD, J. F.; RUESSLER, D. S.; CARLSON, A. R. Comparative sensitivity of five species of macrophytes and six species of algae to atrazine, metribuzin, alachlor, and metolachlor. J. Environ. Toxicol. Chem., v. 17, n. 9, p. 1830-1834, 1998.

GAO, J. et al. Uptake and phytotransformation of organophosphorus pesticides by axenically cultivated aquatic plants. J. Agric. Food Chem., v. 48, n. 12, p. 6114$6120,2000$.

GARBISU, C.; ALKORTA, I. Phytoextration: a costeffective plant technology for the removal of metals from the environment. Biores. Technol., v. 77, n. 3, p. 229-236, 2001.

GARCINUNO, R. M.; FERNANDEZ-HERNANDO, P.; CAMARA, C. Evaluation of pesticide uptake by Lupinus seeds. Water Res., v. 37,n. 14, p. 3481-3489, 2003. 
GONZÁLEZ-BARREIRO, O. et al. Corresponding author contact information. removal of triazine herbicides from freshwater systems using photosynthetic microorganisms. Environ. Poll., v. 144, n. 1, p. 266-271, 2006.

HAYES, T. B. et al. Atrazine induces complete feminization and chemical castration in male African clawed frogs

(Xenopus laevis). PNAS, v. 107, n. 10, p. 4612-4617, 2010.

HEALTH CANADA. Atrazine: Government of Canada Publications [H48-10/1-11-1993-IN]. 1993. Disponível em http: <//www.hc-sc.gc.ca/ewh-semt/alt_formats/hecs-sesc/ $\mathrm{pdf} / \mathrm{pubs} /$ water-eau/atrazine/atrazine-eng.pdf $>$. Acesso em: 18 jun. 2006

HOAGLAND, D. R.; ARNON, D. I. The water-culture method for growing plants without soil. Berkeley: Califórnia Agricultural Experiment Station, 1950. 32 p. (Circular, 347)

INSTITUTO BRASILEIRO DE GEOGRAFIA E ESTATÍSTICA - IBGE. Levantamento sistemático da produção agrícola. 2005. Disponível em: $<\mathrm{http}$ // www.ibge.gov.br>. Acesso em: 22 jan. 2006.

KNAUERT, S. et al. Phytotoxicity of atrazine, isoproturon, and diuron to submersed macrophytes in outdoor mesocosms. Environ. Poll., v. 158, n. 1, p. 167-174, 2010

LANYI, K.; DINYA, Z. Photodegradation study of some triazine-type herbicides. Microchem. J., v. 75, n. 1, p. 1-14, 2003.

LANYI, K.; DINYA, Z. Photodegradation study for assessing the environmental fate of some triazine-, urea- and thiolcarbamate-type herbicides. J. B. Microchem., v. 80, n. 1, p. $79-87,2005$

LAWRENCE, J. F. et al. Evaluation of immunoaffinity chromatography as a replacement for organic solvent cleanup of plant extracts for the determination of triazine herbicides by liquid chromatography. J. Chromatogr. A. v. 752, n. 1, p. $147-154,1996$

MARCACCI, S. et al. Conjugation of atrazine in vetiver (Chrysopogon zizanioides Nash) grown in hydroponics. Environ. Exper. Bot., v. 56, n. 2, p. 205-215, 2006

MENTEN, J. O. M. et al. setor de defensivos agrícolas no Brasil. "Sindicato Nacional da Indústria de Produtos para Defesa Agrícola: Dados de Mercado". 2010.

Disponível em: <http://www.sindag.com.br/ dados_mercado.php>. Acesso em: 20 jan. 2011.

MKANDAWIRE, M.; DUDEL, E. G. Accumulation of arsenic in Lemna gibba L. (duckweed) in tailing waters of two abandoned uranium mining sites in Saxony, Germany Sci. Total Environ., v. 336, n. 1, p. 81-89, 2005.
MOHAMMAD, M.; ITOH, K.; SUYAMA, K. Effects of Herbicides on Lemna gibba and Recovery from Damage After Prolonged Exposure. Arch. Environ. Contam. Toxicol., v. 58, n. 3 , p. $605-612,2010$.

OBEK, E.; SASMAZ, A. Bioaccumulation of Aluminum by Lemna gibba L. from Secondary Treated Municipal Wastewater Effluents. Bull. Environ. Contam. Toxicol., v. 86, n. 2 , p. $217-220,2011$.

OLGUÍN, E. J.; SÁNCHEZ-GALVÁN, G.; PÉREZ-PÉREZ, $\mathrm{T}$. Assessment of the phytoremediation potential of salvinia minima baker compared to spirodela polyrrhiza in highstrength organic wastewater. Water Air Soil Poll., v. 181, n. 1, p. $135-147,2008$.

OUTRIDGE, P. M.; RAUSER, W. E.; HUTCHINSON, T. C. Changes in metal-binding peptides due to acclimation to cadmium transferred between ramets of Salvinia minima. Oecologia, v. 88, n.1, p.109-115, 1991

PILON-SMITS, E. Phytoremediation. Ann. Rev. Plant Physiol. Plant Molec. Biol., v. 56, n. 1, p. 15-39, 2005.

PILON-SMITS, E.; PILON, M. Phytoremediation of metals using transgenic plants. Crit. Review. Plant Sci., v. 21, n. 5, p. $439-456,2002$.

PIRES, F. R. et al. Fitorremediação de solos contaminados com herbicidas. Planta Daninha, v. 21, n. 2, p. 335-341, 2003a.

PIRES, F. R. et al. Seleção de plantas com potencial para fitorremediação de tebuthiuron. Planta Daninha, v. 21, n. 3, p. $451-458,2003 b$.

PRADE, L.; HUBER, R.; BIESELER, B. Structures of herbicides in complex with their detoxifying enzyme glutathione-S-transferase explanations for the selectivity of the enzyme in plants. Structure, v. 6, n. 11, p. 1445-1452, 1998.

RICE, P. J.; ANDERSON, T. A.; COATS, J. R. Phytoremediation of herbicide-contamined surface water with aquatic plants. In: KRUGER, E. L.; ANDERSON, T. A.; COATS, J. R. (Ed.). Phytoremediation of soil and water contaminants. Washington, DC: 1997. p. 133-151.

RAI, P. K.; TRIPATHI, B. D. Comparative assessment of Azolla pinnata and Vallisneria spiralis in $\mathrm{Hg}$ removal from G.B. Pant Sagar of Singrauli Industrial region, India.

Environ. Monit. Assess., v. 148, n. 1, p. 75-84, 2009

RODRIGUES, B. N.; ALMEIDA, F. S. Guia de herbicidas. Londrina: IAPAR, 2005. 592 p.

SCHNOOR, J. E. Phytoremediation. Pittsburgh: GroundWater Remediation Technologies Analysis Center, 1997. 31 p. (Technology Evaluation Report TE-97-01) 
SINDICATO NACIONAL DA INDÚSTRIA DE

PRODUTOS PARA DEFESA AGRÍCOLA - SINDAG.

Dados de mercado. 2003. Disponível em: $<\mathrm{http}$ ://

www. sindag.com. br>. Acesso em: 15 dez. 2005.

SINGH, N. et al. Atrazine and simazine degradation in

Pennisetum rhizosphere. Chemosphere, v. 56, n. 3, p. $257-$ 263, 2004.

SURESH, B.; RAVISHANKAR, G. A. Phytoremediation - A novel and promising approach for environmental clean-up.

Crit. Rev. Biotechnol., v. 24, n. 1, p. 97-124, 2004.

TRYON, R. M.; TRYON, A. F. Ferns and allied plants with special reference to Tropical America. New York: Springer-Verlag, 1982. $1985 \mathrm{p}$

TSAO, D. T. Overview of phytotechnologies. Adv.

Biochem. Eng. Biotechnol., v. 78, n. 1, p. 1-50, 2003.
UETA, J. M. Biorremédio é mais eficiente na degradação de herbicidas no solo. 2004. Disponível em: <http://

www. biotecnologia.com. br>. Acesso em: 27 maio 2004.

UETA, J. M. et al. Biodegradação de herbicidas e biorremediação. Biotec. Ci. Desenv., v. 10, n. 1, p. 10-13, 1999.

WARWICK, S. I. Herbicide resistance in weedy plants: physiology and population biology. Ann. Rev. Ecol. Syst., v. 22 , n. 1, p. 95-114, 1991.

WILLIAMS, J. B. Phytoremediation in wetland ecosystems: progress, problems, and potential. Crit. Rev. Plant Sci., v. 21, n. 6 , p. $607-635,2002$.

ZAYED, A.; GOWTHAMAN, S.; TERRY, N. Phytoaccumulation of trace elements by wetland plants I. Duckweed. J. Environ. Qual., v. 27, n. 3, p. 715-721, 1998. 